\title{
Stratigraphy of the
}

Owens Valley Group (Permian),

Southern Inyo Mountains, California

\section{U.S. GEOLOGICAL SURVEY BULLETIN 1692}

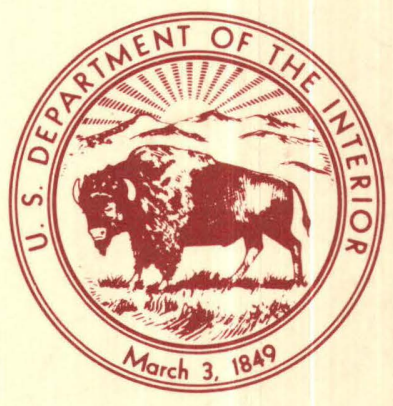



Stratigraphy of the

Owens Valley Group (Permian),

Southern Inyo Mountains, California

By PAUL STONE and CALVIN H. STEVENS

U.S. GEOLOGICAL SURVEY BULLETIN 1692 


\title{
DEPARTMENT OF THE INTERIOR \\ DONALD PAUL HODEL, Secretary
}

\author{
U.S. GEOLOGICAL SURVEY
}

Dallas L. Peck, Director

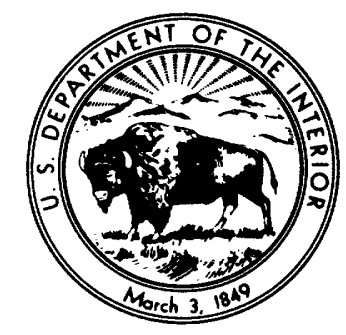

For sale by the

Books and Open-File Reports Section

U.S. Geological Survey

Federal Center, Box 25425

Denver, CO 80225

Library of Congress Cataloging-in-Publication Data

Stone, Paul.

Stratigraphy of the Owens Valley Group (Permian), southern Inyo Mountains, California.

(U.S. Geological Survey Bulletin 1692)

Bibliography

Supt. of Docs. No.: I 19.3:1692

1. Owens Valley Group (Calif.). 2. Geology-CaliforniaInyo Mountains. I. Stevens, Calvin H. II. Title. III. Series:

U.S. Geological Survey Bulletin 1692.

QE75.B9 No. $1692 \quad 557.3 \mathrm{~s}$

$86-600363$

[QE674]

$\left[551.7^{\prime} 56^{\prime} 0979487\right]$ 


\section{CONTENTS}

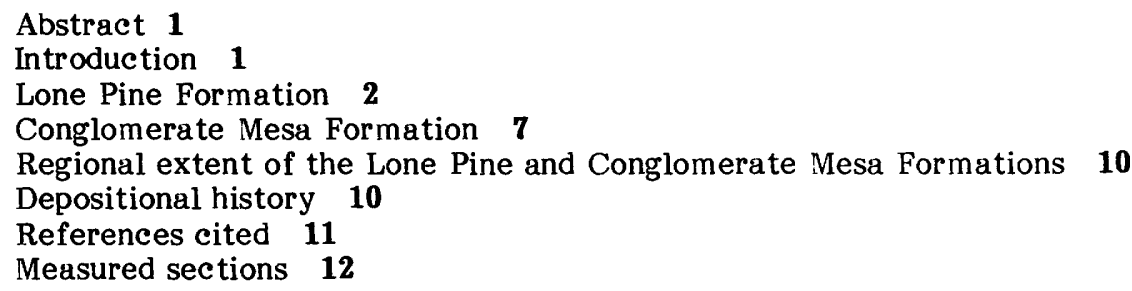

FIGURES

1. Location map of region between Owens and Death Valleys, California 2

2. Chart showing comparison of stratigraphic nomenclature used in this report with that of Merriam and Hall (1957) 3

3. Geologic map of area northwest of Cerro Gordo mine, Inyo Mountains, California 4

4. Measured stratigraphic sections 1-6 6

5. Geologic map of area between Reward mine and Union Wash, Inyo Mountains, California 8 


\title{
Stratigraphy of the Owens Valley Group (Permian), Southern Inyo Mountains, California
}

\author{
By Paul Stone and Calvin H. Stevens
}

\begin{abstract}
The name Owens Valley Formation has been applied to Permian rocks in the southern Inyo Mountains and neighboring ranges since the formation was defined in 1957. Recent work has shown that at its type locality, the Owens Valley Formation consists of a Lower Permian lower part and an Upper Permian upper part that are separated by an angular unconformity. We herein raise the Owens Valley to group rank and introduce the new names Lone Pine Formation and Conglomerate Mesa Formation for the rocks below and above the unconformity, respectively, to make up the group. The Lone Pine Formation is composed of fine-grained sedimentary rocks of deepwater marine origin, mainly calcareous and siliceous mudstone, but locally within its upper part it contains conglomerate and quartzite of shallow-water marine or nonmarine origin (the herein-reassigned Reward Conglomerate Member). The Conglomerate Mesa Formation is composed of sandy limestone, conglomerate, and sandstone of shallow-water marine and nonmarine origin. The unconformity between the Lone Pine and Conglomerate Mesa Formations represents an episode of uplift and tilting during which at least $500 \mathrm{~m}$ of the Lone Pine Formation was locally removed by subaerial erosion.
\end{abstract}

\section{INTRODUCTION}

Merriam and Hall (1957) applied the name Owens Valley Formation to a thick sequence of Permian sedimentary rocks exposed in the southern Inyo Mountains of east-central California, designating a type locality between the Reward mine and Union Wash on the west flank of the range (fig. 1). Recent work has shown that the Owens Valley Formation, at its type locality and elsewhere in the southern Inyo Mountains, consists of a Lower Permian lower part and an Upper Permian upper part that are separated by an angular unconformity (Conley, 1978; Stone and others, 1979, 1980; Stone, 1984; Stone and Stevens, 1984). In this report, we raise the Owens Valley Formation in the southern Inyo Mountains to group rank and introduce the new names Lone Pine Formation and Conglomerate Mesa Formation for the rocks below and above the unconformity, respectively, to make up the group (fig. 2). In an earlier paper (Stone and Stevens, 1984), we used the informal name Formation $A$ for the rocks we herein name the Lone Pine Formation and the informal name Formation $D$ for the rocks we herein nume the Conglomerate Mesa Formation.

In their original description, Merriam and Hall (1957) informally divided the Owens Valley Formation into a lower, a middle, and an upper part. Their lower part consists of not only the rocks that comprise our Lone Pine Formation but also coeval rocks in the Conglomerate Mesa area, the Darwin Hills, and the northern Argus Range that are lithologically distinct from the Lone Pine Formation (fig. 1). We specifically exclude those rocks from the Lone Pine Formation, although we consider them to be part of the Owens Valley Group. The upper part of Merriam and Hall's (1957) Owens Valley Formation is largely equivalent to our Conglomerate Mesa Formation. No rocks equivalent in age or lithology to the middle part of Merriam and Hall's (1957) Owens Valley Formation are present in either the Lone Pine Formation or the Conglomerate Mesa Formation; that stratigraphic interval is represented by the unconformity between the Lone Pine and Conglomerate Mesa Formations. Regional stratigraphic studies (Stone, 1984; Stone and Stevens, 1984) have shown that the middle part of Merriam and Hall's (1957) Owens Valley Formation is largely confined in outcrop distribution to the Conglomerate Mesa area where it was first described.

The type sections of the Lone Pine and Conglomerate Mesa Formations are on a hill Merriam and Hall (1957) informally called Permian Bluff (SE 1/4 New York Butte 15-minute quadrangle), high on the west slope of the Inyo Mountains about $5 \mathrm{~km}$ northwest of the Cerro Gordo mine and about $20 \mathrm{~km}$ southeast of the Reward mine-Union Wash area (fig. 1). The locations of the type sections and five nearby reference sections (primarily in the lenticular, lithologically variable Conglomerate Mesa Formation) are shown on the geologic map of the area around Permian Bluff (fig. 3). These sections (fig. 4) show the lithologic features of the Lone Pine and Conglomerate Mesa Formations better than do sections between the Reward mine and Union Wash, where both formations are extensively altered and metamorphosed. Detailed descriptions of these sections follow the main text. We here designate the type locality of Merriam and Hall's (1957) Owens Valley Formation (herein revised as the Owens Valley Group) as a reference locality for both the Lone Pine and Conglomerate Mesa Formations (fig. 5). 


\section{LONE PINE FORMATION}

The Lone Pine Formation, which is here named after the town of Lone Pine in Owens Valley, Inyo County (fig. 1), conformably overlies the Keeler
Canyon Formation (Merriam and Hall, 1957) of Pennsylvanian and Early Permian age and is unconformably overlain by the Conglomerate Mesa Formation. Where the Conglomerate Mesa Formation is not present, the Lone Pine Formation is

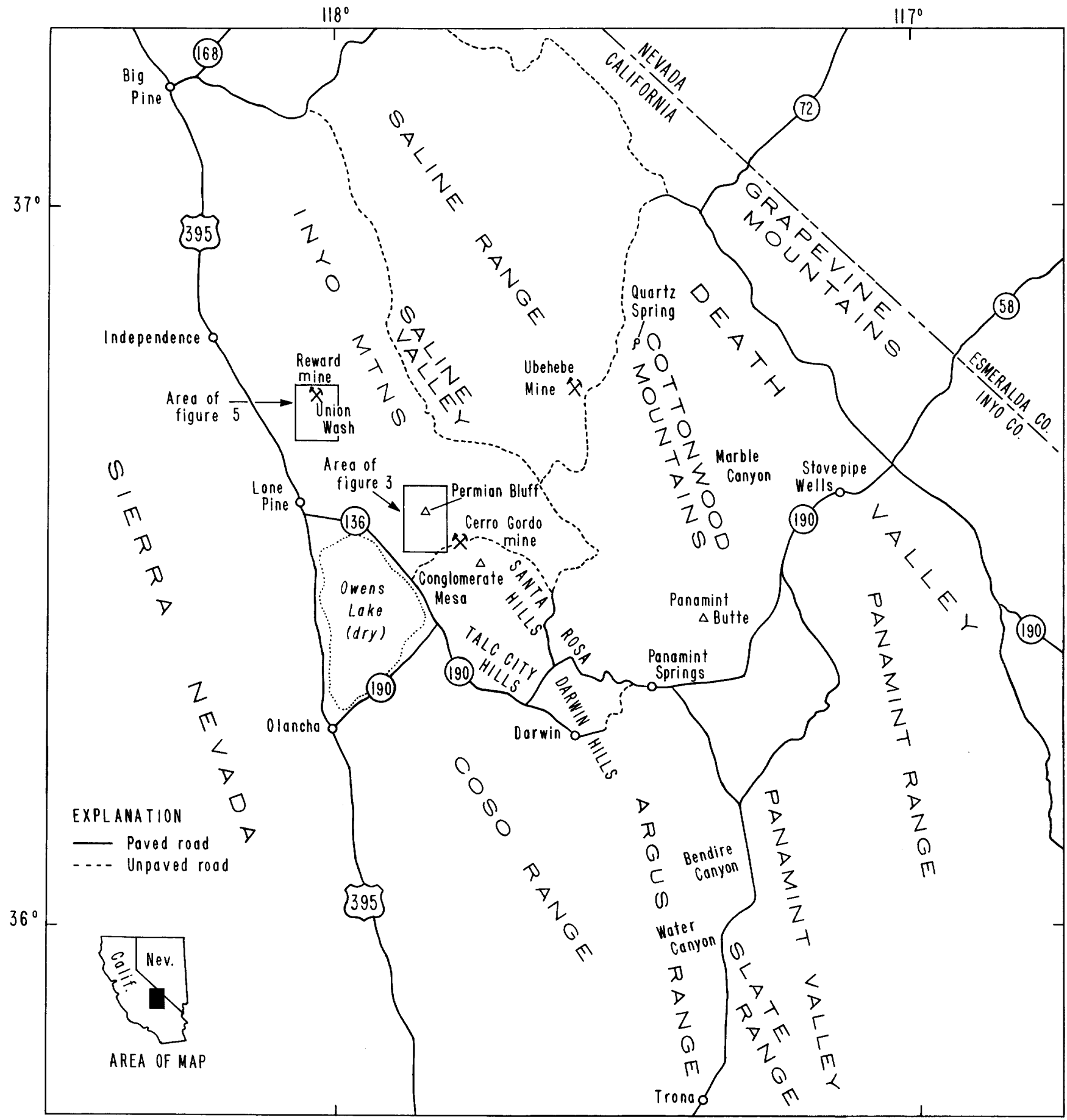

1020 KILOMETERS

Figure 1. Region between Owens and Death Valleys, California, showing type locality of the Owens Valley Group (area of fig. 5), type localities of the Lone Pine and Conglomerate Mesa Formations (areu of fig. 3), and other localities mentioned in text. 
unconformably overlain by unnamed Lower and Middle(?) Triassic strata that have been described by Kirk (1918) and Merriam (1963).

The Lone Pine Formation is here divided into four members (fig. 2). In ascending order, the lower three of these are informally designated members $A$, $B$, and $C$; the uppermost member is the Reward Conglomerate Member, which Kirk (1918) originally named the Reward Conglomerate and which Merriam and Hall (1957) and Ross (1965) later revised to be a member of the Owens Valley Formation. We here reassign the Reward to the Lone Pine Formation. All four members of the Lone Pine Formation are present in the area between the Reward mine and Union Wash (fig. 5). Only members A and B, however, are present at the type locality of the formation (fig. 3), probably owing to erosion of member $\mathrm{C}$ and the Reward Conglomerate Member beneath the unconformity at the base of the overlying Conglomerute Mesa Formation (fig. 2).

At its type locality (fig. 3), the Lone Pine Formation is a slope-forming unit composed mainly of thin-bedded to laminated calcareous mudstone and other fine-grained rocks. The formation contrasts sharply with the underlying Keeler Canyon Formation, which is composed primarily of thick-bedded, mediumto coarse-grained limestone. The type section of the Lone Pine Formation at Permian Bluf (section 1, figs. 3 and 4) has a measured thickness of $309 \mathrm{~m}$; member $\mathrm{A}$ is $237 \mathrm{~m}$ thick and member $\mathrm{B}$ is $72 \mathrm{~m}$ thick.

Member $A$ of the Lone Pine Formation at the type locality consists predominantly of medium- to dark-gray, thin-bedded to laminated calcareous and dolomitic mudstone. The mudstone is composed of microcrystalline calcite and dolomite with less than 10 percent quartz silt, is rich in organic matter, and contains abundant authigenic pyrite. It is interbedded with subordinate medium- to dark-gray, thin-bedded siltstone and very fine to fine-grained sandstone that commonly shows delicate plane lamination and crosslamination. Also present are scattered, relatively thick beds (20 to $80 \mathrm{~cm}$ ) of medium- to dark-gray micritic limestone and dolomite, some of which contain abundant calcified sponge spicules and radiolarians.

Member B consists predominantly of greenishgray, pale-red, yellowish-brown, and pale-brown mudstone, siltstone, and very fine to fine-grained

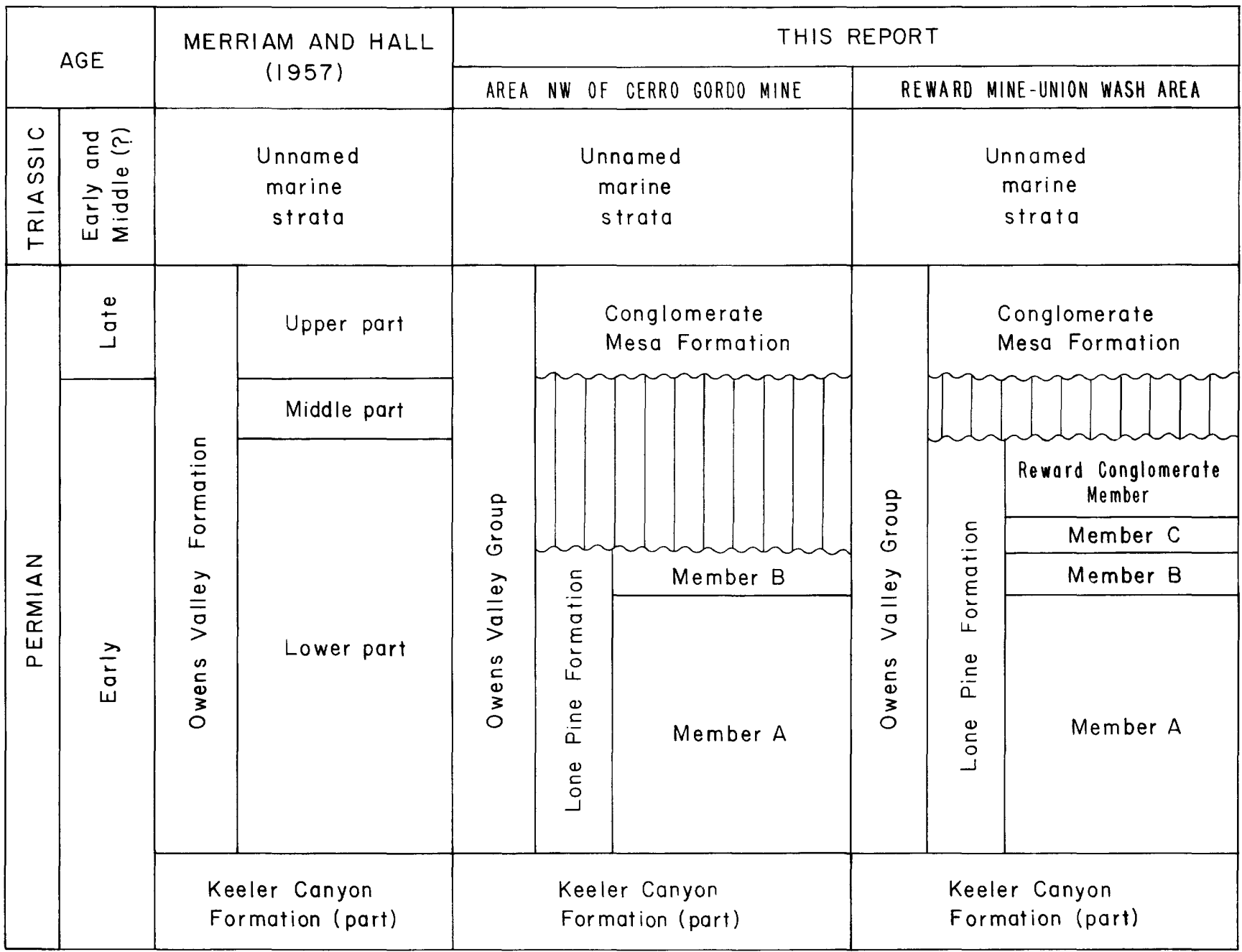

Figure 2. Comparison of stratigraphic nomenclature used in this report with that used by Merriam and Hall (1957). 


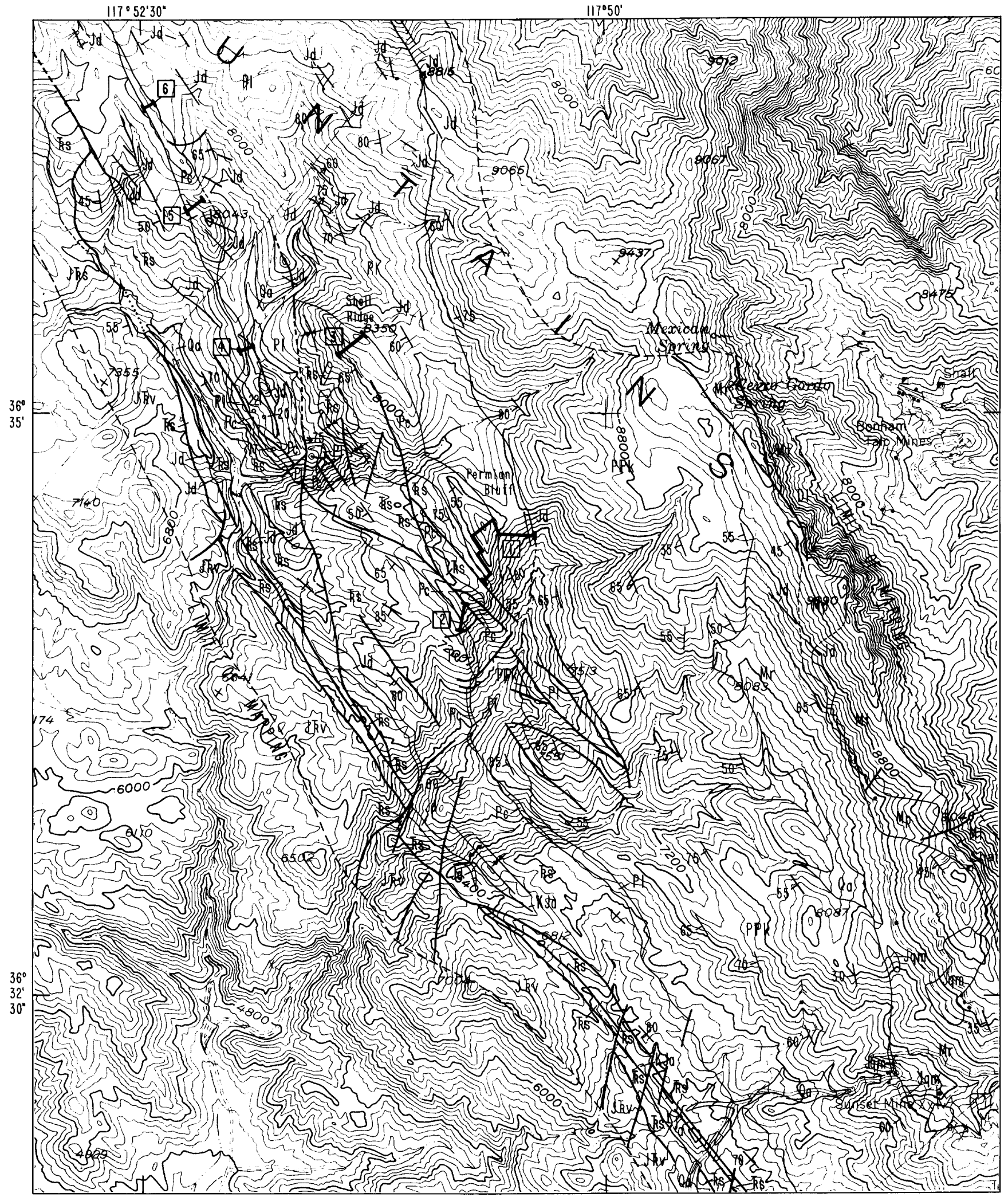

0

2 KILOMETERS

Figure 3. Geologic map of area northwest of Cerro Gordo mine in the Inyo Mountains, California, showing locations of type and reference sections of the Lone Pine and Conglomerate Mesa Formations. See figure 1 for location of map. Base from U.S. Geological Survey, 1:62,500, New York Butte quadrangle, 1950 (contour interval $80 \mathrm{feet}$. Geology mapped in 1974,1975 , and 1982. 
EXPLANATION

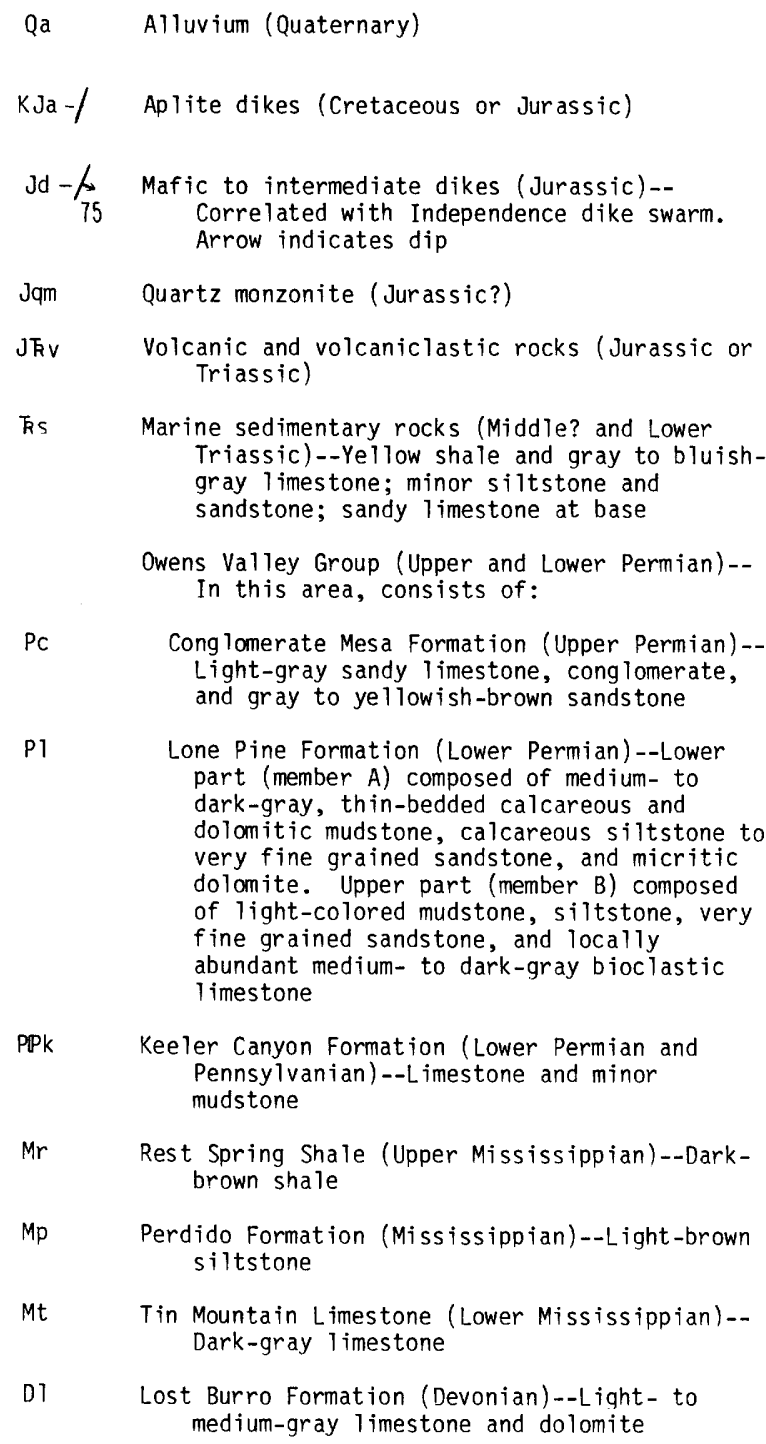

Conglomerate Mesa Formation (Upper Permian)-Light-gray sandy Timestone, conglomerate, and gray to yellowish-brown sandstone

Lone Pine Formation (Lower Permian)--Lower part (member A) composed of medium- to dark-gray, thin-bedded calcareous and dolomitic mudstone, calcareous siltstone to very fine grained sandstone, and micritic dolomite. Upper part (member B) composed of light-colored mudstone, siltstone, very fine grained sandstone, and locally abundant medium- to dark-gray bioclastic limestone

Keeler Canyon Formation (Lower Permian and Pennsylvanian)--Limestone and minor mudstone

$\mathrm{Mr}$

Rest Spring Shale (Upper Mississippian)--Darkbrown shale

Perdido Formation (Mississippian)--Light-brown siltstone

Tin Mountain Limestone (Lower Mississippian)-Dark-gray Timestone

Lost Burro Formation (Devonian)--Light- to medium-gray limestone and dolomite

Contact--Dashed where approximately located

75

Fault--Showing dip. Dashed where approximately located; dotted where concealed

Anticline

Sync 1 ine

Strike and dip of beds

$\stackrel{55}{\perp}$ Inclined

Vertical

Overturned

Line of measured section

Fossil locality

Figure 3. Continued. sandstone that are distinguished from the strata of member A primarily by their lighter color. In addition, mudstone of member B differs from that of member A in being less calcareous and richer in clay minerals. Scattered in member B are relatively thick beds of olive-gray to greenish-gray micritic limestone and dolomite that are like the relatively thick limestone and dolomite beds in member A except in color. The contact between members $A$ and $B$ is gradational over a stratigraphic interval ranging between 10 and $20 \mathrm{~m}$ in thickness.

A short distance northwest of the Lone Pine type section (area of section 4, figs. 3 and 4), member B contains abundant medium- to dark-gray, thin- to thick-bedded bioclastic limestone and limestone conglomerate in addition to light-colored, fine-grained siliceous rocks. The limestone beds, which range in thickness from about $5 \mathrm{~cm}$ to $4.5 \mathrm{~m}$, contain abundant fusulinids, echinodermal debris, brachiopod shell fragments, coral fragments, and angular to subrounded limestone clasts as much as $20 \mathrm{~cm}$ in diameter. Many of the limestone beds are graded and some show convolute lamination and other evidence of softsediment deformation.

The Lone Pine Formation thickens appreciably northwest of its type locality, reaching a thickness of about $1,000 \mathrm{~m}$ in the northwestern part of the area shown in figure 3. Southeast of the type locality, the formation thins and wedges out over a distance of about $3 \mathrm{~km}$ (fig. 3 ), probably as the combined result of depositional thinning and the erosion that was responsible for the unconformity at the top of the formation (Stone, 1984).

Three fusulinid collections from bioclastic limestone beds in member $B$ of the Lone Pine Formation at its type locality (fossil locs. 17, 20, and 22 , fig. 3 ) yielded the following taxa:

$\frac{\text { Schwagerina spp. }}{\text { Pseudoschwagerina ef. }}$. convexu
(Thompson)
$\frac{\text { Cuniculinella aff. C. calx }}{\text { (Thompson and }}$
Wheeler)
Cuniculinella? spp.

This fusulinid assemblage suggests a late Wolfcampian age (Stone, 1984). Beds near the top of the underlying Keeler Canyon Formation contain abundant early middle Wolfcampian fusulinids, establishing the base of the Lone Pine Formation as no older than middle Wolfeampian in age (Merriam and Hall, 1957; Riggs, 1962; Merriam, 1963; Stone, 1984).

In the area between the Reward mine and Union Wash, the Lone Pine Formation, cut by numerous intrusive bodies and extensively altered and silicified, is about $1,000 \mathrm{~m}$ thick. Of this thickness, member $\mathrm{A}$ comprises about $500 \mathrm{~m}$, member $\mathrm{B}$ about $180 \mathrm{~m}$, member $\mathrm{C}$ about $120 \mathrm{~m}$, and the Reward Conglomerate Member about $200 \mathrm{~m}$ (fig. 5). These four units, which were first distinguished by Conley (1978), constitute a conformable sequence that is overlain with angular unconformity by the Conglomerate Mesa Formation. The unconformity truncates the Reward Conglomerate Member and members $\mathrm{C}$ and $\mathrm{B}$ of the Lone Pine Formation from nor thwest to southeast within the area (fig. 5). 


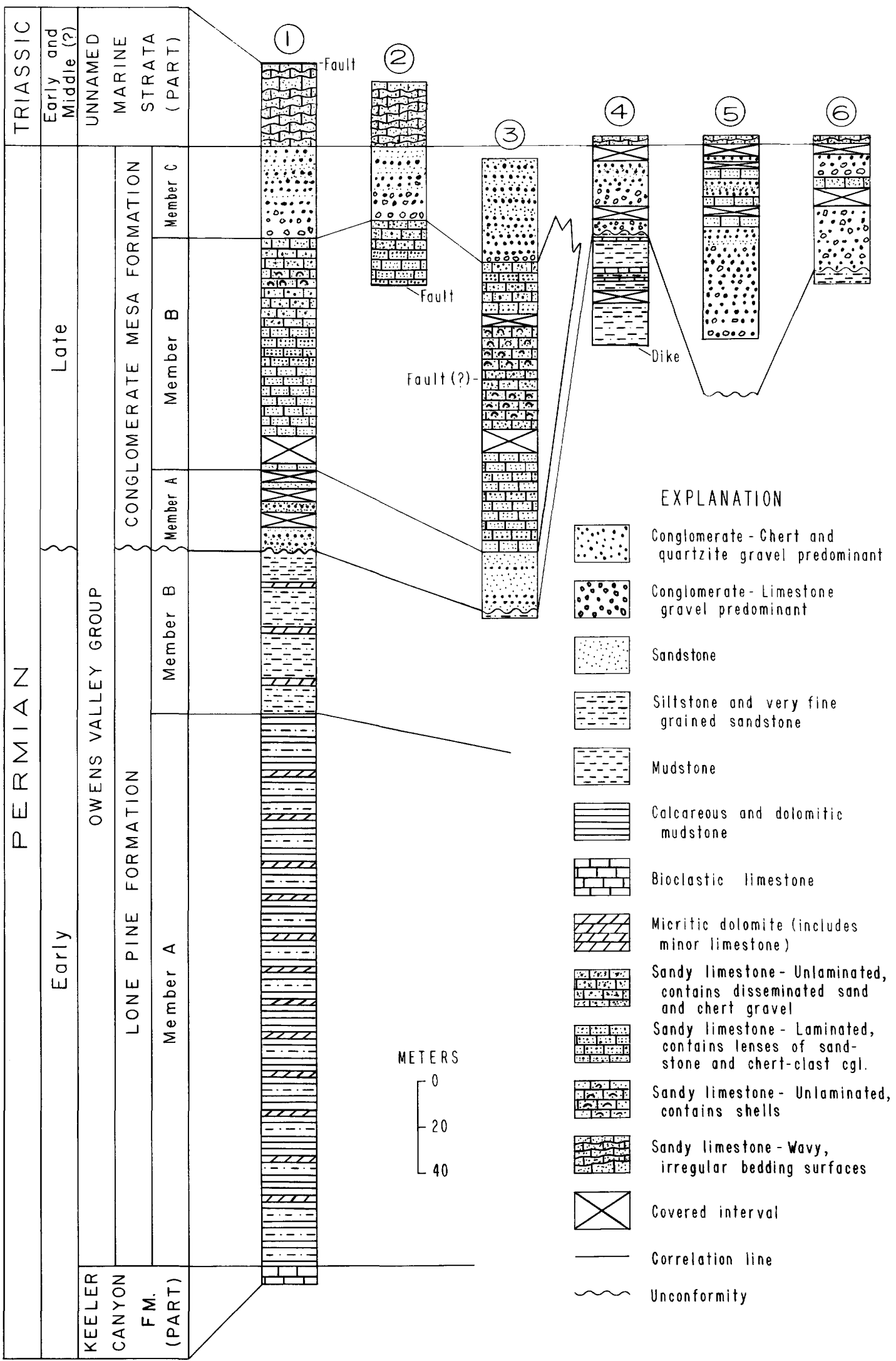

Figure 4. Measured stratigraphic sections 1-6 at type localities of the Lone Pine and Conglomerate Mesa Formations. Section 1 contains type sections of both formations. Locations of sections shown in figure 3. 
Member A, which is particularly well exposed on the south side of Union Wash, consists of reddishbrown-weathering, thin-bedded siliceous hornfels, siltite, and very fine grained quartzite. Thin sections show that much of the silica in this member is of replacement origin; the protoliths probably were dominantly fine-grained calcareous rocks like those in member $A$ of the formation at the type locality. At the head of Union Wash, the basal beds of member A sharply overlie a massive $15-m$-thick bed of limestoneboulder conglomerate that we regard as the uppermost bed in the Keeler Canyon Formation. This boulder bed may be equivalent to the limestone breccia zone that Merriam and Hall (1957, p. 8-9) considered to mark the base of their Owens Valley Formation.

Members $\mathrm{B}$ and $\mathrm{C}$ of the Lone Pine Formation in this area are best exposed on the steep mountain slope directly east of Fossil Hill (fig. 5). Member B is composed of greenish-gray, thin-bedded calc-hornfels and calcareous siltite along with a few thick beds of bioclastic marble. Except for its metamorphosed nature, this unit is lithologically similar to member $B$ of the formation at the type locality. Member $\mathrm{C}$ is composed of massive dark-brown-weathering hornfels interbedded with minor fine- to coarse-grained quartzite and chert-pebble conglomerate. This unit appears to have no lithologic counterpart at the type locality of the Lone Pine Formation.

The Reward Conglomerate Member is a cliffforming unit consisting mainly of thick-bedded, medium - to coarse-grained quartzite and chert-pebble conglomerate. Crossbedding and scour structures are common in these rocks. The lowermost part of the member is marked by a thin, persistent zone of lightgray sandy marble. Kirk (1918) designated no type locality for the Reward Conglomerate, but we consider it to be located about $1 \mathrm{~km}$ south of the Reward mine (NE 1/4 T. 14 S., R. 36 E., Union Wash 7.5-minute quadrangle). However, faulting occurs at the base of the unit at that locality (fig. 5). A better section is present about $0.5 \mathrm{~km}$ southeast of Fossil Hill, where both the stratigraphic base and the unconformably truncated top of the Reward Conglomerate Member are exposed (fig. 5). The Reward Conglomerate Member also is well exposed near Coyote Spring a few kilometers north of the area shown in figure 5 (Ross, 1965). Like the underlying member $C$, the Reward Conglomerate Member is not present at the type locality of the Lone Pine Formation.

The only fossils we have found in the Lone Pine Formation in the area between the Reward mine and Union Wash are poorly preserved inflated fusulinids in the basal part of the Reward Conglomerate Member. These fusulinids could indicate either a Wolfcampian or Leonardian age. Elongate fusulinid molds that we have observed in a similar stratigraphic position near Coyote Spring may represent the typical Leonardian genus Parafusulina. Lithostratigraphic correlations suggest that both member $C$ and the Reward Conglomerate Member are younger than any part of the Lone Pine Formation at its type locality.

The Lone Pine Formation was deposited in environments ranging from deep-water marine for the lower part to nonmarine or very shallow water marine for the upper part. The pyrite-bearing calcareous and dolomitic mudstone that makes up most of the formation at the type locality probably was deposited in deep, quiet, oxygen-poor water on a featureless basin floor, either by slow fallout from suspension or by relatively rapid fallout from dilute turbidity currents. The dolomite presumably is of diagenetic origin. The thin interbeds of laminated siltstone and sandstone probably ure turbidites. We interpret the bioclastic and conglomeratic limestone beds in member $B$ as sediment-gravity-flow deposits derived from basin-rimming carbonate banks or shelves. The abundunt soft-sediment deformation features in these beds suggest deposition in a slope environment. The lithologic characteristics of the coarsely clastic Reward Conglomerate Member suggest that this member was deposited in either an alluvial-fan or a high-energy nearshore-m arine environment.

\section{CONGLOMERATE MESA FORMATION}

The Conglomerate Mesa Formation is here named after Conglomerate Mesa, which is located about $5 \mathrm{~km}$ south of the Cerro Gordo mine (fig. 1). This lenticular formation unconformably overlies the Lone Pine Formation and is paraconformably overlain by unnamed marine strata of Early and Middle(?) Triassic age. The formation is composed primarily of sandy limestone, sandstone, and conglomerate that typically form rugged cliffs and ridges between the slope-forming Lone Pine Formation and Triassic marine strata.

Near its type locality at Permian Bluff (fig. 3), the Conglomerate Mesa Formation ranges to about 225 $m$ thick in a lenticular outcrop belt $8 \mathrm{~km}$ long. Northwest and southeast of this outcrop belt, the Conglomerate Mesa Formation is missing and Triassic strata unconformably overlap the Lone Pine Formation. Because no angular discordance with the overlying Triassic strata exists, we interpret the lenticularity of the Conglomerate Mesa Formation to be the product of depositional thinning rather than postdepositional erosion.

The type section of the Conglomerate Mesa Formation at Permian Bluff (section 1, figs. 3 and 4) has a thickness of $173 \mathrm{~m}$ and is here divided into three informally designated members. In ascending order, these are called members $\mathrm{A}, \mathrm{B}$, and $\mathrm{C}$, which are 34 , 99 , and $40 \mathrm{~m}$ thick, respectively. In an incomplete section at hill 8350 (the informally numed Shell Ridge of Merriam and Hall, 1957) (section 3), members A and $B$ are 26 and $125 \mathrm{~m}$ thick, respectively; in another incomplete section $0.8 \mathrm{~km}$ south of Permian Bluf $\mathrm{f}$ (section 2), member $\mathrm{C}$ is $32 \mathrm{~m}$ thick.

Member $\mathrm{A}$ of the Conglomerate Mesa Formation at the type locality consists of grayish-orange to yellowish-brown, fine- to coarse-grained quartzitic sandstone and sandy conglomerate. Most of the sandstone is plane laminated or gently crosslaminuted. The conglomerate is arranged in welldefined size-sorted layers averaging 10 to $15 \mathrm{~cm}$ thick. Clasts in the conglomerate are mostly angular pebbles of white to light-gray chert.

Member B consists of light-gray, thick-bedded sandy limestone that stands out in rugged hogbacks above the somewhat less resistant underlying rocks. The limestone is composed of 60 to 85 percent 


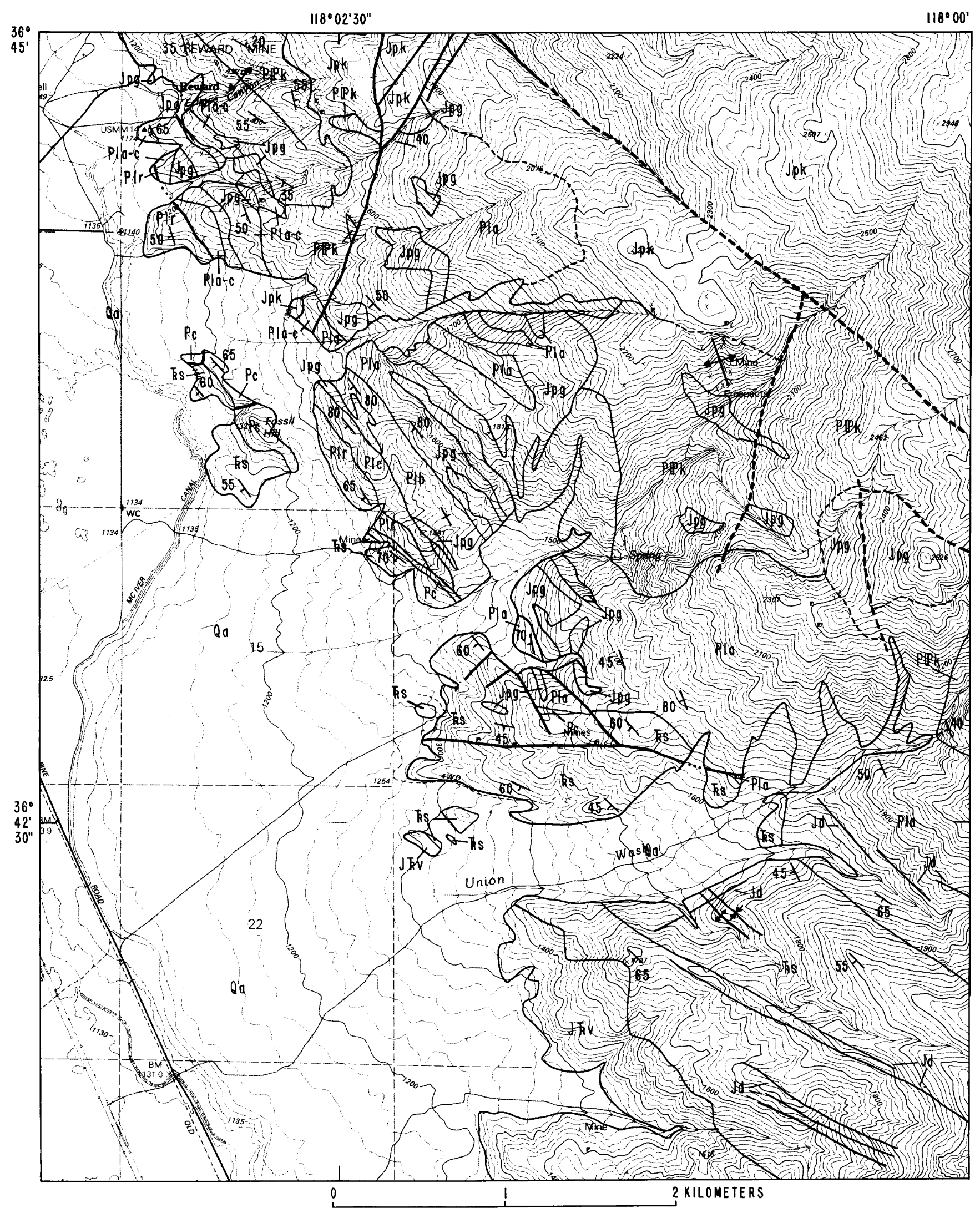

Figure 5. Geologic map of area between Reward mine and Union Wash, Inyo Mountains, California (type locality of Owens Valley Group). See figure 1 for location of map. Base from U.S. Geological Survey, 1:24,060, Union Wash quadrangle, 1982 (contour interval 20 meters). Geology mapped in 1981. 
echinodermal sand and 15 to 40 percent quartz sund, tightly cemented with calcite. Limestone in the lower part of the unit, although massive in general appearance, is plane laminated on a fine scale and alternates with thin lenses and beds of course-grained sandstone and chert-pebble conglom erate. In contrast, limestone in the upper part of the unit is unlaminated, lacks distinct interbeds of sandstone and

\section{EXPLANATION}

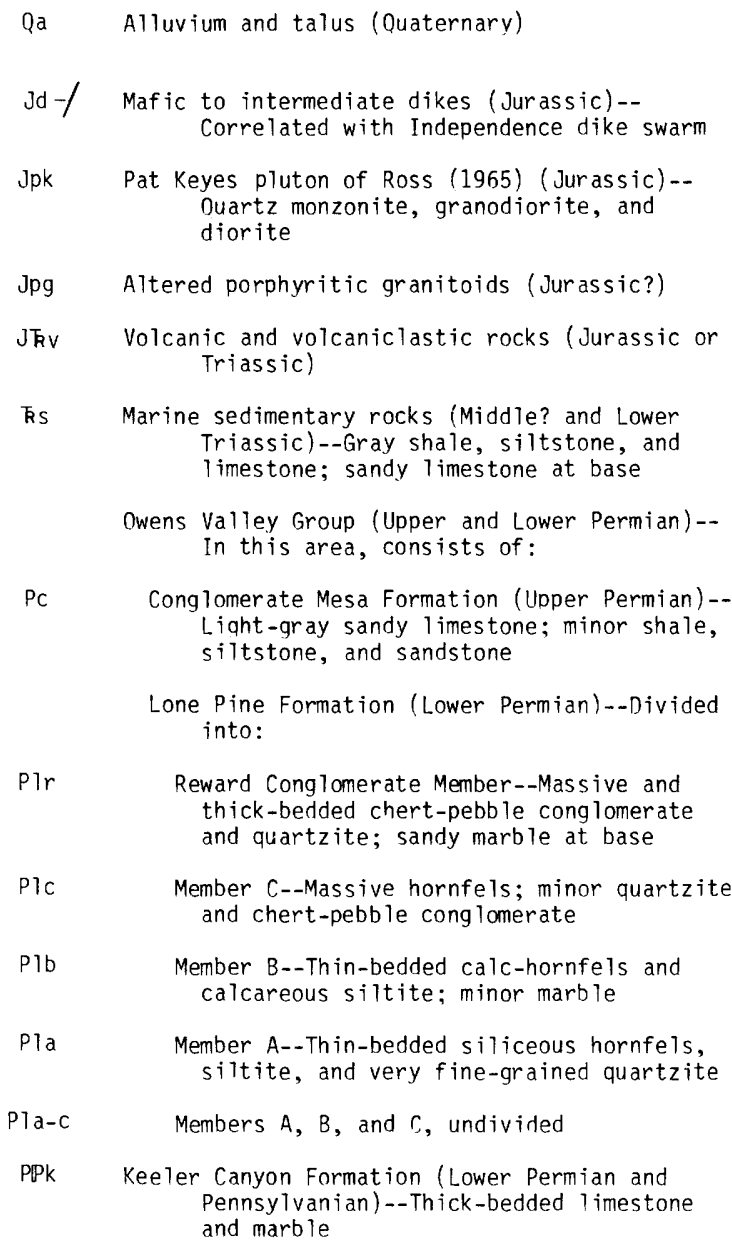

Contact--Dashed where approximate ly located

Fault--Dashed where approximately located, dotted where concealed

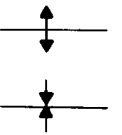

Anticline

Syncline

Strike and dip of beds

$\stackrel{55}{\perp}$ Inclined

Vertical

Figure 5. Continued. conglomerute, and contains randomly distributed coarse sand and chert pebbles. Whole and fragmented shells, mostly brachiopods and gastropods, are locally abundant in the unlaminated limestone but are not present in the laminated limestone.

Member $\mathrm{C}$ is composed of conglomerate, conglomeratic sandstone, and sandstone. Conglomerate dominates the lower part of the unit and sandstone the upper part. The conglomerate, which ranges from massive to well bedded, contains angular to subrounded chert, quartzite, and limestone clasts in a poorly sorted, fine- to coarse-grained sandstone matrix. Among the limestone clasts are (1) light-gray sandy limestone similar in lithology to that in the immediately underlying member $\mathrm{B}$; (2) medium- to dark-gray, fusulinid-bearing limestone similar in lithology to that in member $B$ of the Lone Pine Formation; and (3) light-gray, fusulinid- and coralbearing limestone similar in lithology and fossil content to Lower Permian limestone that we have examined near Conglomerate Mesa. The chert clasts, most of which are white to light gray, and the quartzite clasts generally are of pebble size; the limestone clasts commonly are of cobble or boulder size. The sandstone that makes up most of the upper part of the member is predominantly yellowish brown, thin bedded, and fine grained. Plane lamination, ripple-crosslamination, and ripple marks are developed locally. The sandstone is interbedded with subordinate thin conglom eratic layers.

West of the area of sections 1,2 , and 3 (fig. 3 ), member $B$ of the Conglomerate Mesa Formation thins and wedges out, and on the next line of ridges to the west (area of sections 4, 5, and 6) the formation has a maximum thickness of about $100 \mathrm{~m}$ and is composed mainly of conglomerate and sandstone. However, a thick lens of sandy limestone like that of member $B$ is present near the top of the formation at hill 8043 (section 5), and thinner lenses of the same lithology are present nearby as seen in section 6 .

The Conglomerate Mesa Formation at the type locality is overlain by gray to brownish-gray sandy limestone that marks the base of the thick, unnamed Lower and Middle(?) Triassic marine sequence described by Merriam (1963). This limestone, which is characterized by wavy, ir regular bedding, the presence of dark-gray limestone nodules, and the local abundance of tiny, phosphate-filled gastropod shells, stands out in bold hogbacks above the underlying sandstone and conglom erate.

In the area between the Reward mine and Union Wash, where it overlies the Lone Pine Formation with an angular discordance of about $15^{\circ}$, the Conglomerate Mesa Formation forms a lenticular outcrop belt about $3 \mathrm{~km}$ long (fig. 5). Within this belt the formation thickens northwestward from a wedgeout near Union Wash to about $150 \mathrm{~m}$ on Fossil Hill. The section at Fossil Hill, the base of which is covered by alluvium, consists of about $50 \mathrm{~m}$ of yellowish-brown silts tone and sandstone overlain successively by a thin zone of pink shale and about $100 \mathrm{~m}$ of cliff-forming light-gray sandy limestone. The limestone is lithologically similar to that of member $B$ of the formation in the type section. Sections near the formational wedgeout consist entirely of sandy limestone. A persistent brachiopod coquina at the top of the Conglomerate 
Mesa Formation can be traced from Fossil Hill southeastward to the formational wedgeout, providing evidence that the wedgeout is the result of southeastward depositional onlap. The coquina is sharply but concordantly overlain by 30 to $40 \mathrm{~m}$ of mottled, medium- to dark-gray, irregularly bedded sandy limestone. We correlate this mottled limestone with the basal sandy limestone of the unnamed Lower and Middle(?) Triassic sequence that overlies the Conglomerute Mesa Formation at its type locality. This limestone contains tiny gastropod shells like those in the basal beds of the Triassic sequence elsewhere in the southern Inyo Mountains.

The contact between the Conglomerate Mesa Formation and the overlying 30 to $40 \mathrm{~m}$ of Triassic sandy limestone in the area between the Reward mine and Union Wash is subtle, although sharp, because both units are of generally similar lithology. Kirk (1918) did not recognize this contact and defined a single formation, the Owenyo Limestone, to comprise both of these units; he considered the Owenyo to be entirely Permian in age. Merriam and Hall (1957) did not recognize this contact either and revised the Owenyo as a member of the Permian Owens Valley Formation. Outside the Reward mine-Union Wash area, however, as at Permian Bluff, the uppermost rocks of the Conglomerate Mesa Formation and the lowermost rocks of the overlying Triassic sequence are of markedly different lithology and have always been assigned to separate formations (Merriam and Hall, 1957; Merriam, 1963; Stone, 1984; Stone and Stevens, 1984). Thus, the name Owenyo is not applicable outside the Reward mine-Union Wash area. Therefore, we here abandon the little-used name Owenyo and reassign the rocks of its lower part to the Conglomerate Mesa Formation and those of its upper part to the overlying unnamed Lower and Middle(?) Triassic sequence.

Brachiopods, gustropods, and rare cephalopods of relatively young Permian age have long been known in sandy limestone that we assign to the Conglomerate Mesa Formation (Kirk, 1918; Merriam and Hall, 1957; Gordon and Merriam, 1961; Merriam, 1963). The presently accepted age of Late Permian (late Guadalupian) for these rocks is based on the reported presence of the ammonoid Timorites, a primary index fossil of the Upper Permian Capitanian Stage of Furnish (1973), in beds exposed near the type section of the Conglomerate Mesa Formation (Gordon and Merriam, 1961). The associated brachiopods, which Gordon and Merriam (1961) and earlier workers considered to be typical early Guadalupian species, are now thought to have been misidentified (Wardlaw and Collinson, 1978, p. 1179).

The Conglomerate Mesa Formation was deposited in nonmarine and very shallow water marine environments. Conglomerate and sandstone in the formation most likely are alluvial-fan or braidedstream deposits, although some of these rocks may be of shallow-water marine origin. The sandy limestone probably was deposited in a variety of wave-dominated intertidal to shallow-subtidal marine environments. The laminated facies of the sandy limestone probably represents strandline deposition, whereas the unlaminated, shell-bearing facies probably represents shoreface deposition.

\section{REGIONAL EXTENT OF THE LONE PINE AND CONGLOMERATE MESA FORMATIONS}

The Lone Pine Formation is present throughout much of the southern Inyo Mountains, encompassing rocks mapped by previous workers (Merriam, 1963; Ross, 1965) as part of the Owens Valley Formation. The formation also is present near the Ubehebe mine in the southern extension of the Last Chance Range (fig. 1), encompassing rocks mapped by McAllister (1956) as the shale and upper limestone members of the Bird Spring(?) Formation and by Burchfiel (1969) as the Owens Valley Formation. As noted earlier, the Lone Pine Formation is not recognized in the Conglomerate Mesa area, the Darwin Hills, or the northern Argus Range, where coeval rocks are of such strongly contrasting lithology that different formational names must be used (Stone and Stevens, 1984). Lower Permian rocks in the central Argus Range, the Cottonwood Mountains, and the Panamint Range (fig. 1) resemble those in the northern Argus Range and also are excluded from the Lone Pine Formation.

We have identified the Conglomerate Mesa Formation at three localities in addition to its type locality and the area between the Reward mine and Union Wash-(1) the Conglomerate Mesa area in the southeastern Inyo Mountains and the (2) Bendire Canyon and (3) Water Canyon areas in the central Argus Range. The rocks herein assigned to the Conglomerate Mesa Formation in these areas were previously mapped as part of the Owens Valley Formation (Hall and McKevett, 1962; Moore, 1976). In all three areas, the Conglomerate Mesa Formation is conformably overlain by Lower and Middle(?) Triassic strata correlative with those that overlie the formation at its type locality and in the area between the Reward mine and Union Wash.

\section{DEPOSITIONAL HISTORY}

The Lone Pine Formation was deposited largely in a deep marine basin that regional studies (Stone, 1984; Stone and Stevens, 1984) have shown lay near the edge of the western continental margin of North America. By late Wolfcampian or early Leonardian time, when the Reward Conglomerate Member was accumulating, this basin had shoaled and probably had become subaerially exposed. An ensuing episode of uplift, tilting, and erosion probably spanned most of Leonardian and part of Guadalupian time. At least 500 $m$ of strata (the combined thickness of members B, C, and the Reward Conglomerate Member of the Lone Pine Formation) was removed by erosion in the area between the Reward mine and Union Wash. The shallow-water marine and nonmarine Conglomerate Mesa Formation and the paraconformably overlying Lower and Middle(?) Triassic strata were deposited after this episode of uplift and erosion, which evidently ended by the late Guadalupian. 
Burchfiel, B.C., 1969, Geology of the Dry Mountain quadrangle, Inyo County, California: California Division of Mines and Geology Special Report 99, $19 \mathrm{p}$.

Conley, D.E., 1978, Stratigraphy and depositional history of the Owens Valley Formation at the type locality, Inyo County, California: San Jose, Calif., San Jose State University, M.S. thesis, 63 p.

Furnish, W.M., 1973, Permian stage names, in Logan, A., and Hills, L.V., eds., The Permian and Triassic Systems and their mutual boundary: Alberta Society of Petroleum Geologists Memoir 2, p. 522548.

Gordon, Mackenzie, Jr., and Merriam, C.W., 1961, Late Permian ammonoids in the Inyo Range, California, and their significance, in Geological Survey Research 1961: U.S. Geological Survey Professional Paper 424-D, p. D238-D239.

Hall, W.E., and MacKevett, E.M., Jr., 1962, Geology and ore deposits of the Darwin quadrangle, Inyo County, California: U.S. Geological Survey Professional Paper 368, 87 p.

Kirk, Edwin, 1918, Stratigraphy of the Inyo Range, in Knopf, Adolph, A geologic reconnaissance of the Inyo Range and the eastern slope of the southern Sierra Nevada, California: U.S. Geological Survey Professional Paper 110, p. 19-48.

McAllister, J.F., 1956, Geology of the Ubehebe Peak quadrangle, Inyo County, California: U.S. Geological Survey Geologic Quadrangle Map GQ95, scale $1: 62,500$.

Merriam, C.W., 1963, Geology of the Cerro Gordo Mining District, Inyo County, California: U.S. Geological Survey Professional Paper 408, 83 p.

Merriam, C.W., and Hall, W.E., 1957, Pennsylvanian and Permian rocks of the southern Inyo Mountains,
California: U.S. Geological Survey Bulletin 1061A, $13 \mathrm{p}$.

Moore, S.C., 1976, Geology and thrust fault tectonics of parts of the Argus and Slate Ranges, Inyo County, California: Seattle, Wash., University of Washington, Ph.D. dissertation, $128 \mathrm{p}$.

Riggs, E.A., 1962, Fusulinids of the Keeler Canyon Formation, Inyo County, California: Urbana, \#l., University of Illinois, Ph.D. dissertation, $133 \mathrm{p}$.

Ross, D.C., 1965, Geology of the Independence quadrangle, Inyo County, California: U.S. Geological Survey Bulletin 1181-O, 64 p.

Stone, Paul, 1984, Stratigraphy, depositional history, and paleogeographic significance of Pennsylvanian and Permian rocks in the Owens Valley-Death Valley region, California: Stanford, Calif., Stanford University, Ph.D. dissertation, 399 p.

Stone, Paul, and Stevens, C.H., 1984, Stratigraphy and depositional history of Pennsylvanian and Permian rocks in the Owens Valley-Death Valley region, eastern California, in Lintz, Joseph, Jr., ed., Western geological excursions, v. 4: Geological Society of America, Field Trip Guidebook, 1984 annual meeting, p. 94-119.

Stone, Paul, Stevens, C.H., and Cavit, C.D., 1980, A regional Early Permian angular unconformity in eastern California [abs.]: Geological Society of America Abstracts with Programs, v. 12, no. 3, p. 154.

Stone, Paul, Stevens, C.H., and Conley, D.E., 1979, Late Permian orogenic strata in the southern Inyo Mountains, California [abs.]: Geological Society of America Abstracts with Programs, v. 11, no. 3, p. 130.

Wardlaw, B.R., and Collinson, J.W., 1978, Stratigraphic relations of Park City Group (Permian) in eastern Nevada and western Utah: American Association of Petroleum Geologists Bulletin, v. 62, p. 11711184. 


\section{MEASURED SECTIONS}

(Locations shown on fig. 3; generalized lithology shown on fig. 4)

Section 1. Type section of the Conglomerate Mesa and Lone Pine Formations. Measured at Permian Bluff in August 1974.

Thickness meters

Top of section faulted.

Unnamed marine strata (Lower and Middle? Triassic) (incomplete):

Limestone, sandy, and calcareous sandstone, fine to medium grained in beds 2 to $25 \mathrm{~cm}$ thick. Limestone, light to medium gray; commonly weathers grayish orange; locally mottled; bedding surfaces wavy and irregular. Sandstone, light brown to brownish gray; bedding surfaces planar. Rare beds and lenses of coarse-grained sandstone and chert-pebble conglomerate 3 to $25 \mathrm{~cm}$ thick. Interval forms craggy hogbacks.............

Incomplete thickness unnamed Lower and Middle(?) Triassic sedimentary rocks.....

Paraconformable contact.

Conglomerate Mesa Formation (Upper

Permian):

Member $\mathrm{C}$ :

2. Sandstone ( 40 percent), conglomerate (40 percent), and cover ( 20 percent). Sandstone, calcareous, light gray to yellowish brown or grayish orange; fine to coarse grained, locally conglomeratic; moderately to well sorted; beds 1 to $10 \mathrm{~cm}$ thick; laminated. Conglomerate, composed of 30 to 50 percent gravel in a calcareous sandstone matrix; beds 5 to $50 \mathrm{~cm}$ thick. Gravel is white to gray chert (angular to subangular, median diameter $5 \mathrm{~mm}$ to $1 \mathrm{~cm}$; maximum diameter $6 \mathrm{~cm}$ )........

1. Conglomerate, composed of 40 to 60 percent gravel in a light-gray to grayishorange calcareous sandstone matrix; beds $15 \mathrm{~cm}$ to $1 \mathrm{~m}$ thick; gravel generally oriented parallel to bedding. Gravel is 50 to 60 percent white to gray chert (angular to subangular, median diameter $5 \mathrm{~mm}$ to $1 \mathrm{~cm}$, maximum diameter $10 \mathrm{~cm})$; 20 to 30 percent gray, fine-grained calcareous quartzite (angular to subrounded, medium diameter $3 \mathrm{~cm}$, maximum diameter $10 \mathrm{~cm}$ ); 5 to 20 percent light-gray sandy limestone (angular to subrounded, median diameter $5 \mathrm{~cm}$, maximum diameter $70 \mathrm{~cm}$ ); and 0 to 10 percent 1 ight- to dark-gray bioclastic limestone containing echinodermal debris and fusulinids (angular to subrounded, median diameter $8 \mathrm{~cm}$, maximum diameter $50 \mathrm{~cm}$ ). Lenticular interbeds of fine- to coarse-grained, laminated and crosslaminated sandstone less than $20 \mathrm{~cm}$ thick.....

Total thickness member c...............

Member B:

5. Limestone (calcarenite), sandy; light
Section 1: Upper Permian-Continued

Conglomerate Mesa Formation--Continued Member B--Continued

to medium light gray, grayish orange, and yellowish brown; generally fine to medium grained but locally contains coarse-grained quartz sand and white to dark-gray, angular to subangular chert gravel to $1 \mathrm{~cm}$ in diameter; poorly sorted; massively bedded but commonly fractures along wavy surfaces 2 to $5 \mathrm{~mm}$ apart; echinodermal debris abundant; silicified brachiopods (including a punctate spiriferid) and gastropods (including Euphemitopsis) present

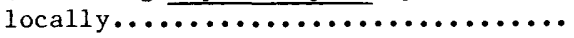

4. Limestone (calcarenite), sandy, 1ight to medium light gray and grayish orange; fine to medium grained, well sorted; massively bedded but plane laminated to gently crosslaminated; lamination defined by differences in sand content. Interbedded with numerous lenses of sandy chert-pebble conglomerate 2 to $30 \mathrm{~cm}$ thick (chert gravel white to gray, subangular to rounded, median diameter $5 \mathrm{~mm}$ ); plane lamination and low-angle crosslamination common. Interbeds of yellowish-brown, fine- to medium-grained calcareous sandstone $5 \mathrm{~mm}$ to $1 \mathrm{~cm}$ thick present in basal $5 \mathrm{~m}$ of interval. Interval

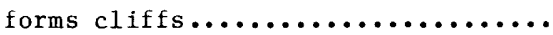

3. Limestone (calcarenite), sandy, and minor calcareous sandstone; interval about 50 percent covered. Limestone, light gray to grayish orange, very fine grained, indistinctly bedded; contains scattered laminations and thin beds of medium- to coarse-grained sandstone and chert-pebble conglomerate (chert gravel white to gray, subangular to rounded, medium diameter $5 \mathrm{~mm}$ ). Sandstone, grayish orange to yellowish brown, locally conglomeratic; beds 7 to $25 \mathrm{~cm}$ thick; rarely laminated....................

2. Covered interval...............

1. Limestone (calcarenite), sandy, grayish orange to yellowish brown; fine to medium grained; beds 5 to $15 \mathrm{~cm}$ thick...................

Total thickness member В............. 98.8

Member A:

6. Covered interval................

5. Sandstone, calcareous, grayish orange to yellowish brown, fine to medium grained; beds 5 to $8 \mathrm{~cm}$ thick........

4. Covered interval................

3. Sandstone ( 70 percent) and conglomerate ( 30 percent), grayish orange to yellowish brown, thin bedded. Sandstone, fine to coarse grained and locally conglomeratic. Conglomerate, composed of subangular to rounded, white to gray chert gravel (median diameter $5 \mathrm{~mm}$ to $1 \mathrm{~cm}$, maximum 
Section 1: Upper Permian--Continued

Conglomerate Mesa Formation--Continued Member A--Continued

diameter $3 \mathrm{~cm}$ ) in a calcareous sandstone matrix; gravel concentrated in planar laminations............

2. Covered interval...............

1. Sandstone ( 60 percent) and conglomerate (40 percent), calcareous, yellowish brown; beds 2 to $25 \mathrm{~cm}$ thick. Sandstone, laminated, fine to medium grained. Conglomerate, composed of angular to subangular, white to gray chert gravel (median diameter $5 \mathrm{~mm}$ to $1 \mathrm{~cm}$, maximum diameter $5 \mathrm{~cm}$ ) in a calcareous sandstone matrix; gravel oriented parallel to bedding.........

Total thickness member A...............

Total thickness Conglomerate Mesa

Formation.....................

Unconformable contact.

Lone Pine Formation (Lower Permian): Member B:

Interval about 30 percent covered. Exposed part of interval consists of mudstone, siltstone, and very fine to fine-grained sandstone ( 95 percent) and dolomite and limestone ( 5 percent). Mudstone, siltstone, and sandstone occur as graded beds 4 to $15 \mathrm{~cm}$ thick that typically consist of, from base to top: $5 \mathrm{~mm}$ to $2 \mathrm{~cm}$ of pale-red to pale-brown, plane-laminated to crosslaminated calcareous sandstone; 2 to $4 \mathrm{~cm}$ of pale-brown to grayish-orange calcareous to noncalcareous siltstone; and 2 to $10 \mathrm{~cm}$ of greenish-gray to palebrown micaceous noncalcareous mudstone. Basal bed contacts sharp. Dolomite and limestone, micritic, olive gray to greenish gray; beds 10 to $30 \mathrm{~cm}$ thick and spaced an average of about $7 \mathrm{~m}$ apart. Member grades transitionally upward from top of member A.........

Total thickness member B...............

Member A:

Interval about 25 percent covered. Exposed part of interval consists of mudstone (65 percent), siltstone and very fine to fine-grained sandstone ( 30 percent), and limestone and dolomite ( 5 percent). Mudstone, calcareous, pyritic and rich in organic material; medium to dark gray; beds $1 \mathrm{~mm}$ to $20 \mathrm{~cm}$ thick; fissile. Siltstone and sandstone, calcareous, medium to dark gray, commonly weathers grayish orange to yellowish brown; beds $5 \mathrm{~mm}$ to $6 \mathrm{~cm}$ thick; plane laminated and crosslaminated; ripple marks present locally; bases and tops of beds sharp. Limestone and dolomite, generally micritic but rarely calcarenitic, medium light to dark gray, commonly weathers grayish orange to yellowish brown; beds 15 to $80 \mathrm{~cm}$ thick and spaced an average of 6 to

Section 1: Lower Permian--Continued

Lone Pine Formation--Continued

Member A--Continued

Thickness

meters

$4 \cdot 3$

5.8

$\underline{9.0}$

33.8

$\underline{172.6}$

\section{3}

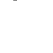 coarsely crystalline calcite. All lithologies characterized by even, planar bedding................. and tops of beds sharp; many beds have tension gashes filled with

237.0

Total thickness member A...............

Total thickness Lone Pine Formation........ 237.0 308.5

Conformable contact (poorly exposed, obscured by dikes).

Keeler Canyon Formation (Lower Permian and Pennsylvanian) (not measured):

Limestone (calcarenite) and mudstone. Limestone, bioclastic and silty, medium to dark gray, medium to thick bedded, coarse-grained; shows $\mathrm{Ta}, \mathrm{Tb}$, and Tc divisions of the Bouma sequence; echinodermal debris and fusulinids locally abundant; forms craggy resistant outcrops. Mudstone, calcareous, dark gray, laminated, nonresistant..................

Section 2. Conglomerate Mesa Formation (incomplete). Measured $0.8 \mathrm{~km}$ south of Permian Bluff in August 1974.

op of section conformably overlain by additional unnamed marine strata of Early and Middle(?) Triassic age.

Unnamed marine strata (Lower and Middle? Triassic) (incomplete):

Limestone, sandy, and calcareous sandstone; medium gray, commonly weathers yellowish brown; locally mottled; fine grained; beds average about $3 \mathrm{~cm}$ thick; bedding surfaces crinkled and irregular; rare thin interbeds of chert-pebble

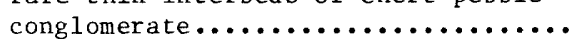

Incomplete thickness unnamed Lower and Middle(?) Triassic sedimentary rocks.....

Paraconformable contact.

Conglomerate Mesa Formation (Upper Permian)

(incomplete):

Member C:

3. Sandstone ( 85 percent) and conglomerate (15 percent). Sandstone, yellowish brown, fine grained; beds 1 to $10 \mathrm{~cm}$ thick; laminated. Conglomerate, composed of 30 to 35 percent gravel in a poorly sorted, fine- to coarse-grained calcareous sandstone matrix; beds 20 to $30 \mathrm{~cm}$ thick. Gravel is 85 to 90 percent white to lightgray chert and medium-gray calcareous quartzite (angular to subrounded, median diameter $5 \mathrm{~mm}$ to $1 \mathrm{~cm}$, maximum diameter $4 \mathrm{~cm}$ ) and 10 to 15 percent medium-gray limestone (median diameter 1 to $2 \mathrm{~cm}$,
Thickness m eters

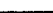


Section 2: Upper Permian--Continued

Conglomerate Mesa Formation--Continued Member C--Continued

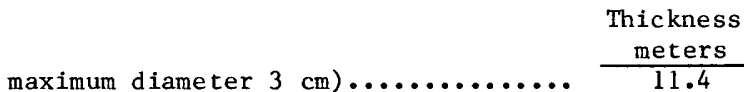

2. Conglomerate, composed of 30 to 50 percent gravel in a poorly sorted, fineto coarse-grained calcareous sandstone matrix; beds $15 \mathrm{~cm}$ to $1.5 \mathrm{~m}$ thick, decreasing in thickness gradually from base to top of interval; gravel generally oriented parallel to bedding. Gravel is 30 to 40 percent white to gray chert (angular to subangular, median diameter $5 \mathrm{~mm}$ to $1 \mathrm{~cm}$, maximum diameter $7 \mathrm{~cm}$ ); 15 to 30 percent lightto medium-gray bioclastic limestone containing fusulinids (angular to subrounded, median diameter 3 to $5 \mathrm{~cm}$, maximum diameter $18 \mathrm{~cm}$ ); 15 to 30 percent light- to medium-gray calcareous quartzite (subangular to subrounded, median diameter 2 to $3 \mathrm{~cm}$, maximum diameter $9 \mathrm{~cm}$ ); and 15 to 25 percent 1 ight-gray sandy limestone (angular to subrounded, median diameter 2 to $3 \mathrm{~cm}$, maximum diameter $20 \mathrm{~cm}$ ). Median gravel size and percentage of limestone gravel decrease gradually from base to top of interval. Scattered interbeds of lightto medium-gray, fine-grained calcareous sandstone generally less than $2 \mathrm{~cm}$ thick........................

1. Conglomerate, composed of 50 percent gravel in a poorly sorted, fine- to coarse-grained calcareous and argillaceous matrix; massive; gravel generally oriented parallel to bedding. Gravel is 30 to 35 percent gray chert (angular to subangular, median diameter $5 \mathrm{~mm}$ to $1 \mathrm{~cm}$, maximum diameter $14 \mathrm{~cm}$ ); 30 to 35 percent light- to medium-gray bioclastic limestone containing echinodermal debris and fusulinids (subangular to subrounded, median diameter $10 \mathrm{~cm}$, maximum diameter $75 \mathrm{~cm})$; 10 to 15 percent light-gray sandy limestone (median diameter 5 to $6 \mathrm{~cm}$, maximum diameter $45 \mathrm{~cm}$ ); and 5 to 10 percent calcareous quartzite (subangular to subrounded, median diameter 1 to $2 \mathrm{~cm}$, maximum diameter $12 \mathrm{~cm}) \ldots$

Total thickness member $c: \ldots \ldots \ldots \ldots \ldots \ldots$

Member B (incomplete):

5. Limestone (calcarenite) (75 percent) and conglomerate ( 25 percent); intergradational vertically and laterally; beds generally less than $5 \mathrm{~cm}$ thick, lenticular. Limestone, sandy, grayish orange to yellowish brown, fine to medium grained. Conglomerate, composed of 40 to 60 percent gravel in a poorly sorted, fine- to coarse-grained calcareous sandstone matrix; gravel generally oriented parallel to bedding. Gravel is more than 95 percent gray chert and calcareous quartzite (angular to subangular, median diameter 3 to $4 \mathrm{~mm}$, maximum diameter $2 \mathrm{~cm}$ ) and less than 5 percent light- to medium-gray limestone (median diameter 1 to $2 \mathrm{~cm}$, maximum diameter $4 \mathrm{~cm}$ )..................
Section 2: Upper Permian-Continued Conglomerate Mesa Formation--Continued Member B--Continued

4. Limestone (calcarenite), sparsely sandy, light to medium gray, massively bedded but commonly fractures along wavy surfaces $2 \mathrm{~mm}$ to $1 \mathrm{~cm}$ apart; locally contains bryozoans, brachiopod shells, and coarse echinodermal debris. Thin lenticular interbeds of coarse-grained sandstone and chert-pebble conglomerate...................

3. Conglomerate, composed of 40 to 60 percent gravel in a poorly sorted, fine-to coarse-grained calcareous sandstone matrix; massive; gravel subrounded to rounded, discoidal, and generally oriented parallel to bedding. Gravel is 60 to 70 percent gray calcareous quartzite (median diameter 2 to $3 \mathrm{~cm}$, maximum diameter $10 \mathrm{~cm}$ ) and 30 to 40 percent gray chert (median diameter $1 \mathrm{~cm}) . . \ldots \ldots \ldots \ldots \ldots . . . . .$.

2. Sandstone, calcareous, yellowish brown, medium to coarse grained and locally conglomeratic; gravel is gray chert (maximum diameter $5 \mathrm{~mm}$ ); beds 1 to $2 \mathrm{~cm}$ thick.........................

1. Limestone (calcarenite), sandy, light gray, commonly weathers light brown; massively bedded but finely laminated; generally fine grained but locally contains medium- to coarse-grained quartz sand and coarse echinodermal debris. Lenticular interbeds of sandy chert-pebble conglomerate 5 to $15 \mathrm{~cm}$ thick (maximum gravel diameter $1 \mathrm{~cm}) \ldots \ldots \ldots \ldots \ldots \ldots \ldots \ldots \ldots \ldots \ldots \ldots$

Incomplete thickness member B.......... 26.9

Incomplete thickness Conglomerate Mesa Formation........................

Base of section faulted.

Section 3. Conglomerate Mesa Formation (incomplete). Measured at hill 8350 (Shell Ridge) in August and September 1974.

Thickness meters

Top of section covered by colluvium and talus. Top of section about 40 to $50 \mathrm{~m}$ below base of unnamed Lower and Middle(?) Triassic marine strata.

Conglomerate Mesa Formation (Upper Permian) (incomplete):

Member C (incomplete):

3. Sandstone ( 50 percent) and conglomerate (50 percent). Sandstone, calcareous, grayish orange to pale red; generally fine to medium grained but locally coarse grained to conglomeratic; beds $3 \mathrm{~mm}$ to $3 \mathrm{~cm}$ thick; grades laterally into conglomerate. Conglomerate, 
Section 3: Upper Permian--Continued Conglomerate Mesa Formation--Continued Member C--Continued
Section 3: Upper Permian-Continued Conglomerate Mesa Formation--Continued Member B--Continued

composed of 25 to 35 percent gravel in a poorly sorted, fine- to coarsegrained sandstone matrix; beds $5 \mathrm{~cm}$ to $1 \mathrm{~m}$ thick. Gravel is more than 95 percent white to light-gray chert (angular to subangular, median diameter $5 \mathrm{~mm}$ to $1 \mathrm{~cm}$, maximum diameter $3 \mathrm{~cm}$ ) and less than 5 percent light-gray calcareous quartzite (subrounded, median diameter $2 \mathrm{~cm}$, maximum diameter

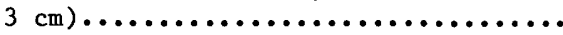

2. Conglomerate ( 80 percent) and sandstone (20 percent). Conglomerate, composed of 25 to 35 percent gravel in a poorly sorted, fine- to coarse-grained sandstone matrix; beds $15 \mathrm{~cm}$ to $1 \mathrm{~m}$ thick; gravel oriented parallel to bedding. Gravel is 60 to 90 percent white to light-gray chert and medium-gray calcareous quartzite (angular to subrounded, median diameter $1 \mathrm{~cm}$, maximum diameter $6 \mathrm{~cm}$ ); and 10 to 40 percent 1 ight- to medium-gray limestone, some sandy and some bioclastic (angular to subrounded, median diameter 1 to $2 \mathrm{~cm}$, maximum diameter $8 \mathrm{~cm}$ ). Sand stone, calcareous, grayish orange to pale red, fine to medium grained; forms intervals 1 to $2 \mathrm{~m}$ thick between conglomerate intervals; beds 1 to $2 \mathrm{~cm}$ thick; grades laterally and vertically into conglomerate.....................

1. Conglomerate, composed of 50 percent gravel in a poorly sorted, fine- to coarse-grained sandstone matrix; massive in lower part of interval, beds $15 \mathrm{~cm}$ to $1 \mathrm{~m}$ thick in upper part. Gravel is 35 to 40 percent light-gray sandy limestone (subangular to subrounded, median diameter 4 to $8 \mathrm{~cm}$, maximum diameter $50 \mathrm{~cm}) ; 15$ to 40 percent light- to medium-gray bioclastic limestone containing echinodermal debris and fusulinids (angular to subrounded, median diameter 5 to $10 \mathrm{~cm}$, maximum diameter $50 \mathrm{~cm}) ; 20$ to 25 percent white to light-gray chert (angular to subangular, median diameter $1 \mathrm{~cm}$, maximum diameter $8 \mathrm{~cm}$ ); and 5 to 25 percent light- to medium-gray calcareous quartzite (subangular to subrounded, median diameter 3 to $4 \mathrm{~cm}$, maximum diameter $8 \mathrm{~cm}$ ). Median gravel size decreases from base to top of interval. Channeling observed at base of interval................

Incomplete thickness member c............

Member B:

7. Limestone (calcarenite), sandy, light gray to pale brown; generally fine to medium grained but contains scattered coarse-grained siliceous sand and chert gravel; massive. Lenticular interbeds of chert-pebble conglomerate present throughout; conglomerate lenses containing imestone cobbles and boulders present in upper $7 \mathrm{~m} . . . . . . . . . . . . . . . . . .$.

6. Covered interval.................

5. Limestone (calcarenite), sandy, light gray; generally fine to medium grained but contains abundant coarse-grained siliceous sand, chert gravel (maximum diameter $5 \mathrm{~cm}$ ), coarse echinodermal debris, and whole and fragmented brachiopod and gastropod shells; thick bedded to massive. Limestone is locally replaced by large irregular patches of pale-red to brown jasperoid......................

Break in section; covered interval about $30 \mathrm{~m}$ wide that may mark the trace of a minor fault across which a small amount of section may be cut out or duplicated.

4. Limestone (calcarenite), sandy, light to medium gray and grayish orange; generally fine to medium grained but contains abundant coarsegrained siliceous sand, chert gravel, coarse echinodermal debris, and whole and fragmented brachiopod and gastropod she1ls; thick bedded to massive. Irregular patches of pale-red to grayish-orange jasperoid present

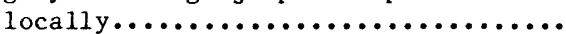

3. Interval largely covered; scattered outcrops of sandy limestone as in the underlying interval...............

2. Limestone (calcarenite), sandy, light to medium gray and grayish orange, fine to medium grained, well sorted; massive in general appearance but plane laminated to gently crosslaminated on a fine scale; alternates with lenticular interbeds of coarsegrained calcareous sandstone and chertpebble conglomerate generally about 2 to $10 \mathrm{~cm}$ thick but locally as thick as $75 \mathrm{~cm}$ (median gravel diameter

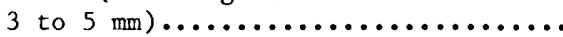

1. Limestone (calcarenite), sandy, grayish orange, fine to medium grained; fractures into slabs less than $2 \mathrm{~cm}$ thick..........................

Total thickness member $B . \ldots \ldots \ldots \ldots \ldots \ldots$.

Member A:

4. Sandstone, calcareous, light gray, fine to medium grained, indistinctly bedded; interval more than 50 percent

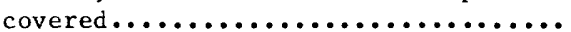

3. Conglomerate, composed of 60 percent gravel in a poorly sorted, fine- to coarse-grained sandstone matrix; gravel concentrated in size-sorted layers 10 to $15 \mathrm{~cm}$ thick and 
Section 3: Upper Permian-Continued Conglomerate Mesa Formation--Continued Member A-Continued

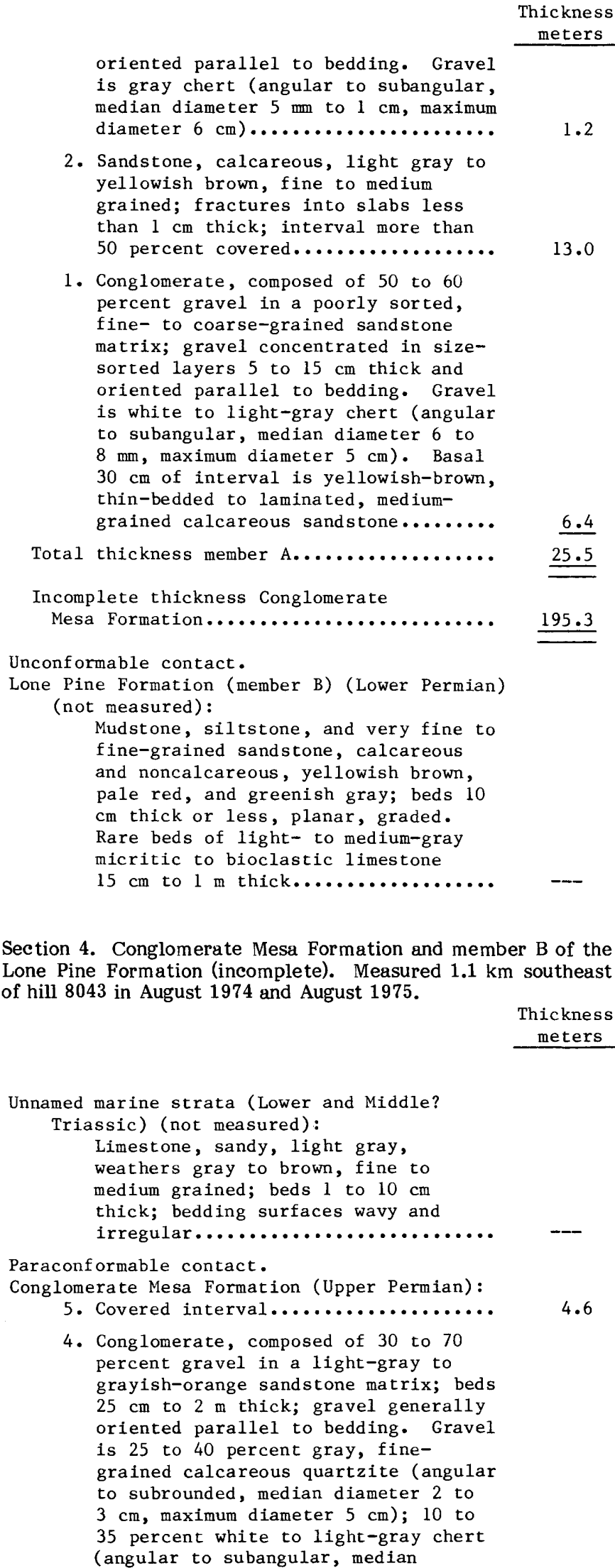

Section 4: Upper Permian-Continued

Conglomerate Mesa Formation--Continued

Thickness

meters

diameter 5 to $8 \mathrm{~mm}$, maximum diameter $2 \mathrm{~cm}) ; 5$ to 40 percent light- to dark-gray bioclastic limestone (angular to subrounded, median diameter 2 to $4 \mathrm{~cm}$, maximum diameter $10 \mathrm{~cm}$ ); and 5 to 40 percent light-gray sandy limestone (subangular to subrounded, median diameter 2 to $5 \mathrm{~cm}$, maximum diameter $15 \mathrm{~cm}$ ). Lenticular interbeds of yellowish-brown, fine-grained calcareous sandstone less than $20 \mathrm{~cm}$

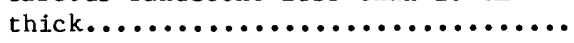

3. Conglomerate, composed of 35 to 70 percent gravel in a poorly sorted, fine- to medium-grained sandstone matrix; massive; gravel generally oriented parallel to bedding. Gravel is 30 percent light- to medium-gray, fine-grained calcareous quartzite (subangular to subrounded, median diameter 2 to $3 \mathrm{~cm}$, maximum diameter $10 \mathrm{~cm}) ; 25$ to 30 percent light-gray sandy limestone (subangular to subrounded, median diameter 2 to $5 \mathrm{~cm}$, maximum diameter $20 \mathrm{~cm}$ ); 20 to 25 percent white to light-gray chert (angular to subangular, median diameter $5 \mathrm{~mm}$, maximum diameter $3 \mathrm{~cm}$ ); and 10 to 15 percent light- to darkgray bioclastic limestone (subangular to subrounded, median diameter 3 to $5 \mathrm{~cm}$, maximum diameter $25 \mathrm{~cm}) \ldots \ldots$...

2. Covered interval.................

1. Conglomerate, composed of 75 percent gravel in a poorly sorted, fine- to coarse-grained sandstone matrix; massive; gravel generally oriented parallel to bedding. Gravel is 30 to 50 percent medium- to dark-gray bioclastic limestone containing echinodermal debris and fusulinids (subangular to subrounded, median diameter 3 to $6 \mathrm{~cm}$, maximum diameter $30 \mathrm{~cm}) ; 25$ to 45 percent white to light-gray chert (angular to subangular, median diameter 5 to $7 \mathrm{~mm}$, maximum diameter $3 \mathrm{~cm}$ ); and 10 to 20 percent light-gray to pale-red calcareous siltstone, very fine grained sandstone, and quartzite (angular to subangular, tabular, median diameter 1 to $2 \mathrm{~cm}$, maximum diameter $3 \mathrm{~cm}$ ). Median gravel diameter decreases gradually from base to top of interval .........................

Total thickness Conglomerate

Mesa Formation.....................

Unconf ormable contact.

Lone Pine Formation (Lower Permian) (incomplete): Member B (incomplete):

9. Siltstone and very fine grained sandstone, calcareous, yellowish brown; beds $2 \mathrm{~mm}$ to $2 \mathrm{~cm}$ thick; fractures into thin slabs...................

8. Limestone, medium gray; one bed (Bouma $\mathrm{Ta})$; grades from limestone conglomerate 
Section 4: Lower Permian--Continued

Lone Pine Formation--Continued

Member B--Continued

at base to medium-grained calcarenite

at top; lower part of bed contains

echinodermal debris, fusulinids, other

bioclasts, and limestone clasts to

$3 \mathrm{~cm}$ in diameter; matrix micritic; base

and top of bed sharp.............

7. Siltstone and mudstone, calcareous, yellowish brown; beds $2 \mathrm{~mm}$ to $8 \mathrm{~cm}$ thick; fractures into thin, irregular slabs. Minor (less than 5 percent of interval) medium-gray, fine- to coarsegrained bioclastic limestone; beds 5 to $10 \mathrm{~cm}$ thick, graded and ungraded. Rare thin-bedded to laminated, greenishgray mudstone...................

6. Limestone (calcarenite), medium gray; one bed (Bouma Tab); grades from coarse grained at base to fine grained at top; upper $10 \mathrm{~cm}$ plane laminated.........

5. Siltstone, calcareous, yellowish brown, thin bedded and laminated; minor greenish-gray mudstone.............

4. Limestone, medium gray; one bed (Bouma Tab); grades from limestone conglomerate at base to fine-grained calcarenite at top; maximum clast diameter $1 \mathrm{~cm}$; echinodermal debris abundant, fusulinids rare; upper

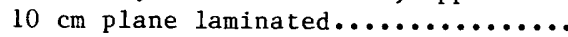

3. Siltstone, calcareous, yellowish brown, thin bedded to laminated. Scattered beds of medium-gray bioclastic limestone 5 to $7 \mathrm{~cm}$ thick....

2. Covered interval................

1. Siltstone, calcareous, yellowish brown, thin bedded to laminated; scattered beds of medium-gray, fineto coarse-grained bioclastic limestone 5 to $30 \mathrm{~cm}$ thick. Limestone beds show $\mathrm{Ta}$ and $\mathrm{Tb}$ divisions of the Bouma sequence...................... Incomplete thickness Lone Pine Formation...

Base of section cut by dike.
Incomplete thickness member B...........

Section 5: Upper Permian

Conglomerate Mesa Formation

Thickness

meters

Conglomerate Mesa Formation (Upper Permian) (incomplete):

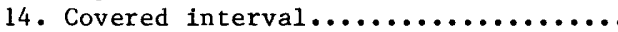

13. Sandstone, conglomeratic, calcareous; light gray to yellowish brown; beds $15 \mathrm{~cm}$ to $1 \mathrm{~m}$ thick; contains about 15 percent gravel. Gravel is 40 to 50 percent white to light-gray chert (angular to subangular, median diameter 5 to $7 \mathrm{~mm}$, maximum diameter $5 \mathrm{~cm}$ ); 40 to 50 percent gray to grayish-red calcareous sandstone (angular to subrounded, median diameter $1 \mathrm{~cm}$, maximum diameter $5 \mathrm{~cm}$ ); 0 to 5 percent mediumgray bioclastic limestone containing echinodermal debris and fusulinids (angular to subangular, median diameter 2 to $3 \mathrm{~cm}$, maximum diameter $9 \mathrm{~cm}$ ); and 0 to 5 percent light-gray sandy limestone (subangular to subrounded, median diameter $2 \mathrm{~cm}$, maximum diameter

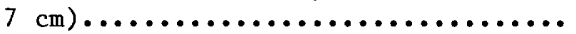

12. Covered interval ..............

11. Limestone (calcarenite), sandy, light to medium gray, fine to medium grained; beds $40 \mathrm{~cm}$ to $1 \mathrm{~m}$ thick; contains lenses of coarse-grained sandstone and chertpebble conglomerate generally less than $5 \mathrm{~cm}$ thick (chert gravel angular to subangular, maximum diameter $1 \mathrm{~cm}$.

10. Conglomerate, composed of white to dark-gray chert gravel (angular to subrounded, maximum diameter $2 \mathrm{~cm}$ ) in a 1ight-gray to yellowish-brown, poorly sorted calcarenitic sandstone matrix.......................

9. Limestone (calcarenite), sandy, light gray, fine to coarse grained, locally conglomeratic..................

8. Conglomerate, composed of white to dark-gray chert gravel (angular to rounded, median diameter 4 to $5 \mathrm{~mm}$, maximum diameter $2 \mathrm{~cm}$ ) in a lightgray to yellowish-brown, poorly sorted, fine- to coarse-grained calcarenitic sandstone matrix; massive..........

7. Limestone (calcarenite), sandy, light gray; beds $2 \mathrm{~cm}$ to $1 \mathrm{~m}$ thick; plane laminated; echinodermal debris abundant. Alternates with beds and lenses of coarse-grained sandstone and chert-pebble conglomerate (chert gravel angular to rounded, maximum

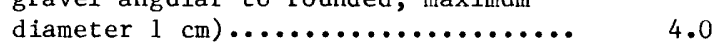

Section 5. Conglomerate Mesa Formation (incomplete). Measured at hill 8043 in August 1974.

Unnamed marine strata (Lower and Middle?

Triassic)(not measured): Limestone, sandy, light gray, fine to medium grained, thin bedded; bedding irregular, wavy; locally mottled due to presence of medium-gray, spherical to elliposoidal calcareous concretions 1 to $2 \mathrm{~cm}$ in diameter...............

Paraconformable contact.
6. Covered interval ...............

5. Limestone (calcarenite), sandy, light to medium gray, fine to medium grained; contains lenses of poorly sorted sandstone and chertpebble conglomerate 2 to $10 \mathrm{~cm}$ thick (chert gravel angular to subangular, maximum diameter $1 \mathrm{~cm}$ ); gradational from underlying unit.....

4. Conglomerate; composed of 40 to 45 percent gravel in a fine- to coarse-grained calcareous sandstone 
Section 5: Upper Permian-Continued Conglomerate Mesa Formation--Continued white to light-gray chert (angular to subangular, median diameter $5 \mathrm{~mm}$ to $1 \mathrm{~cm}$, maximum diameter $6 \mathrm{~cm}$ ); 10 to 15 percent 1 ight-gray calcareous quartzite (subangular to subrounded, median diameter $4 \mathrm{~cm}$, maximum diameter $10 \mathrm{~cm})$; and 5 percent medium-gray bioclastic limestone (subangular to subrounded, median diameter $5 \mathrm{~cm}$, maximum diameter $14 \mathrm{~cm})$. Median gravel diameter decreases gradually from base to top of interval..................

Section crosses dike and talus; stratigraphic relations unclear across break. About $10 \mathrm{~m}$ of section probably obscured.

3. Conglomerate and sandstone, thinly interbedded and lenticular. Conglomerate, composed of 25 to 40 percent gravel in a light- to medium-gray, fine- to coarse-grained calcarenitic sandstone matrix. Gravel is 60 to 90 percent white to dark-gray chert (angular to rounded, median diameter $5 \mathrm{~mm}$ to $1 \mathrm{~cm}$, maximum diameter $8 \mathrm{~cm}$ ); 5 to 30 percent medium-gray calcareous quartzite (subangular to subrounded, median diameter $4 \mathrm{~cm}$, maximum diameter $13 \mathrm{~cm}$ ); and 0 to 5 percent medium-gray bioclastic limestone (subangular to subrounded, median diameter $6 \mathrm{~cm}$, maximum diameter $17 \mathrm{~cm}$ ). Sandstone, calcarenitic, light to medium gray, fine to coarse grained and conglomeratic; grades laterally and vertically into conglomerate........

2. Covered interval................

1. Conglomerate, composed of 50 to 75 percent gravel in a light- to mediumgray or yellowish-brown, fine- to coarse-grained calcarenitic sandstone matrix; beds 1 to $3 \mathrm{~m}$ thick; subtle lamination present; gravel generally oriented parallel to bedding. Gravel is 85 to 95 percent white to dark-gray chert (angular to subrounded, median diameter $1 \mathrm{~cm}$, maximum diameter $10 \mathrm{~cm}$ ); 5 to 15 percent calcareous quartzite (subangular to rounded, median diameter $5 \mathrm{~cm}$, maximum diameter $15 \mathrm{~cm}$ ); and 0 to 5 percent medium-gray bioclastic limestone, some containing fusulinids (subangular to subrounded, median diameter 4 to $5 \mathrm{~cm}$, maximum diameter $24 \mathrm{~cm}$ ). Interval forms cliffs......

Incomplete thickness Conglomerate Mesa Formation...................

Underlying strata covered by talus; base of section probably is about 15 to $25 \mathrm{~m}$ above base of Conglomerate Mesa Formation.

Section 6. Conglomerate Mesa Formation. Measured $1.0 \mathrm{~km}$ nor thwest of hill 8043 in August 1974.

Thickness meters Triassic) (not measured): Limestone, sandy, light to medium gray, weathers light brown, fine grained; bedding surfaces irregular and wavy; poorly exposed...........

Paraconformable contact.

Conglomerate Mesa Formation (Upper Permian):

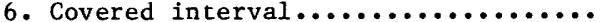

5. Conglomerate, composed of 25 percent gravel in a light-gray, fine- to coarsegrained calcareous sandstone matrix; beds 5 to $15 \mathrm{~cm}$ thick. Gravel is 95 percent 1ight- to dark-gray chert (angular to subangular, median diameter 5 to $8 \mathrm{~mm}$, maximum diameter $5 \mathrm{~cm}$ ); 5 percent light-gray sandy limestone (subangular to subrounded, median diameter 3 to $4 \mathrm{~cm}$, maximum diameter $10 \mathrm{~cm})$; and less than 1 percent mediumgray bioclastic 1imestone (angular to subangular, median diameter $3 \mathrm{~cm}$, maximum maximum diameter $4 \mathrm{~cm}$ )............

4. Conglomerate, composed of 50 percent gravel in a poorly sorted, fine- to coarse-grained sandstone matrix; beds $15 \mathrm{~cm}$ to $1 \mathrm{~m}$ thick. Gravel is 40 to 50 percent light-gray sandy limestone (angular to subrounded, median diameter 7 to $10 \mathrm{~cm}$, maximum diameter $45 \mathrm{~cm}$ ); 40 to 50 percent white to light-gray chert (angular to subangular, median diameter $5 \mathrm{~mm}$ to $1 \mathrm{~cm}$, maximum diameter $10 \mathrm{~cm}$ ); 5 to 10 percent medium-gray calcareous quartzite (median diameter 3 to $4 \mathrm{~cm}$, maximum diameter $10 \mathrm{~cm}$ ); and 0 to 5 percent medium- to dark-gray bioclastic limestone (angular to subrounded, median diameter $6 \mathrm{~cm}$, maximum diameter $15 \mathrm{~cm}$ ). Median gravel diameter decreases gradually from base to top of interval...............

3. Limestone (calcarenite), sandy, light gray, massive, generally fine to medium grained; locally contains coarse-grained quartz and chert gravel with a maximum diameter of $6 \mathrm{~mm}$. Grades laterally into conglomerate that contains large clasts of similar sandy limestone...........

2. Covered interval ................

1. Conglomerate, composed of 50 percent gravel in a poorly sorted, fine- to coarse-grained sandstone matrix; beds $15 \mathrm{~cm}$ to $1 \mathrm{~m}$ thick except in basal $5 \mathrm{~m}$ where bedding is massive. Gravel is 85 to 95 percent white to 1 ight-gray chert (angular to subangular, median diameter 5 to $8 \mathrm{~mm}$, maximum diameter $8 \mathrm{~cm}$ ) and 5 to 15 percent gray calcareous quartzite (subangular to subrounded, median diameter 3 to $5 \mathrm{~cm}$, maximum

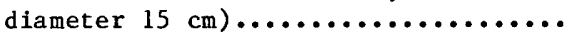

Total thickness Conglomerate Mesa

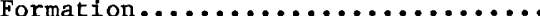


Section 6: Lower Permian

Lone Pine Formation

Unconf ormable contact.

Lone Pine Formation (Lower Permian)

(not measured):

Mudstone, siltstone, and very fine

grained sandstone, grayish orange to

yellowish brown, slightly calcareous,

beds $5 \mathrm{~mm}$ to $1 \mathrm{~cm}$ thick; poorly

exposed......................... 
